\title{
BIOAKTIFITAS BUNGA SEPATU (Hibiscus rosa-sinensis L.) TERHADAP KADAR KOLESTEROL DARAH MENCIT (Mus musculus) YANG MENGALAMI HIPERKOLESTEROLEMIA DENGAN DIET TINGGI LEMAK
}

\author{
Rinza Rahmawati S. ${ }^{1}$ \\ 1) Prodi D3 Analis Kesehatan, FIK, Universitas Muhammadiyah Surabaya \\ rinza_rahmawati@yahoo.com
}

Tangal Submit: 30 November 2017

Tanggal Review:

18 Desember 2017

Tanggal Publish Online:

22 Desember 2017

\begin{abstract}
The purpose of this study was to determine the effect of bioactivity of extract Hibiscus rosa-sinensis $L$. to blood cholesterol level of mice Mus musculus that experienced hypercholesterolemia with high fat diet. This research is a pure experimental research, using randomized post-test only control group design. Hibiscus rosasinensis L.contains anthocyanin pigment which belongs to flavonoid group that acts as antioxidant. Twenty-eight mice were divided into four groups (K1, K2, K3 and K4). The K1 group was the group that received high fat treatment and aquadest after acclimation. Groups $\mathrm{K} 2, \mathrm{~K} 3$, and $\mathrm{K} 4$ are treatment groups treated with high-fat diet, septal extract of $1 \mathrm{ml}$ and aquadest after acclimation. High-fat feeding lasts 28 days. During the research has been done weighing the mouse five times. The results showed that giving $1 \mathrm{ml}$ of extract Hibiscus rosasinensis $L$. for twenty eight days can decrease the cholesterol level of Mus musculus where the value of $\mathrm{p}<0.05$.
\end{abstract}

Keywords : Hibiscus rosa-sinensis L. extract, cholesterol level, high fat diet

\section{PENDAHULUAN}

Tubuh seseorang yang normal mengandung lemak 15-20\% dari berat badan pada pria umur 18-30 tahun dan $20-25 \%$ pada wanita dengan umur yang sama. Kadar jumlah lemak yang melebihi prosentase tersebut maka seseorang dapat dikatakan mengalami obesitas. Seseorang yang mengalami obesitas setelah dewasa dapat mengalami penambahan volume sel lemak tanpa disertai penambahan jumlah sel (Purwati, 2002). Obesitas merupakan salah satu faktor risiko batu empedu kolesterol. Diet pembatasan kalori direkomendasikan pada pasien obesitas dengan batu empedu untuk menurunkan berat badan. Pembatasan asupan kalori dapat dilakukan dengan pemberian Low Calorie Diet (LCD) atau Very Low Calorie diet (VLCD) (Hassel, 2012).

Obesitas ditandai dengan peningkatan massa lemak dan peningkatan sekresi kolesterol empedu. Tingginya kadar kolesterol didalam darah sering disebut juga sebagai hiperkolesterol. Keadaan ini bukanlah suatu penyakit tetapi gangguan metabolik yang bisa 
menyumbang dalam terjadinya berbagai penyakit terutama penyakit kardiovaskuler.

Komponen utama yang dapat meningkatkan resiko penyakit kadriovaskuler adalah low-density lipoprotein (LDL) kolesterol dimana LDL berperan utama dalam mengangkut kolesterol ke jaringan perifer. Sebaliknya high-density lipoprotein (HDL) kolesterol terkait terutama dalam menurunkan resiko pembentukan lesi arterosklerosis. HDL berperan dalam mobilisasi kolesterol dari berkembang dan membentuk arteroma. HDL juga berperan dalam mengangkut kolesterol ke hati untuk diekskresi melalui hempedu (Kumar, et al.,2007).

Kolesterol merupakan salah satu jenis lemak yang memiliki peran penting bagi kehidupan karena kolesterol memiliki peran dalam menyusun dan memperbaiki dinding sel, berperan dalam jaringan syaraf dan memproduksi hormon testoteron, estrogen, kortisol, dan vitamin D. Kolesterol dari makanan mencapai keseimbangan dengan kolesterol plasma dalam beberapa hari dan mencapai keseimbangan dengan kolesterol di jaringan dalam beberapa minggu (Mayes, 2009).

Salah satu upaya untuk menurunkan kadar kolesterol dalam darah dengan penggunaan obat golongan antihiperkolesterol. Pada penggunaan golongan antihiperkolesterol terdapat beberapa kendala diantaranya yaitu waktu terapi yang lama serta menimbulkan efek samping. Rendahnya tingkat kepatuhan penderita meminum obat antihiperkolesterol dapat berpengaruh terhadap keberhasilan pasien mencapai kadar kolesterol yang diharapkan. Pencarian obat terutama yang berasal dari alam sangat giat dilakukan. Salah satu tanaman yang dapat dijadikan pengobatan alternative adalah bunga sepatu.

Bunga sepatu mengandung berbagai macam senyawa kimia. Salah satu kandungan penting yang terdapat pada kelopak bunga kembang sepatu adalah pigmen antosianin yang termasuk golongan flavonoid yang berperan sebagai antioksidan. Potensi antioksidan flavonoid didasarkan pada jumlah dan lokasi gugus hidroksilnya. Flavonoid terdiri dari flavonols dan pigmen antosianin. Antosianin berada dalam bentuk glukosida sementara itu flavonols terdiri dari gossypetin, hibiscetin, dan quercetia. Anthocyanins dan flavonoids meliputi: cyanidin-3,5-diglucoside, cyani-din-3-sophoroside-5-glucoside, quercetin-3,7-diglucoside, quercetin-3diglucoside (Jadhav,2009).

Tujuan Penelitian ini untuk mengetahui bioaktif ekstrak bunga sepatu (Hibiscus rosa-sinensis 1.) terhadap kadar kolesterol darah mencit (Mus musculus) yang mengalami hiperkolesterolemia dengan diet tinggi lemak.

\section{METODE PENELITIAN}

\section{Hewan coba}

Sebanyak dua puluh delapan mencit diperoleh dari Pusvetma surabaya (Pusat Veteriner Farma) jalan Ahmad yani no 68-70 Surabaya. Dua puluh delapan mencit dibagi 
menjadi empat kelompok (K1, K2, K3 dan

K4) Sebelum masuk pada tahap penelitian semua mencit masuk dalam masa aklimatisasi selama tujuh hari.

\section{Pakan tinggi lemak}

Mencit hiperkolesterolmia dibuat dengan cara memberi pakan mencit tersebut dengan kuning telur asin dan kulit ayam yang digoreng krispy. Pemberian pakan tinggi lemak berlangsung selama 28 hari.

\section{Bunga Sepatu}

Ekstrak bunga sepatu diperoleh dengan cara: seluruh bagian bunga sepatu di haluskan dengan blender tanpa penambahan air, sari yang keluar kemudian diencerkan sesuai dengan konsentrasi yang dikehendaki

Prosedur pengambilan darah mencit

Pengambilan darah mencit dilakukan setelah perlakuan terakhir yaitu pada hari ke-39. Sebelum pengambilan darah mencit dipuasakan selama \pm 12 jam . Darah mencit diambil dari jantung dengan menggunakan jarum suntik sebanyak $1 \mathrm{ml}$.

\section{Pemeriksaan Total Kolesterol}

Pengukuran kadar kolesetrol total ditentukan secara enzymatic colorimetric dengan metode CHOD-PAP (Cholesterol Oxidase - Para Aminophenazone).

\section{RANCANGAN PENELITIAN}

Penelitian ini merupakan penelitian eksperimental murni, dengan menggunakan rancangan randomized post test only control group design. Dua puluh delapan ekor dibagi kedalam empat kelompok secara random yaitu:

K1 sebanyak 7 ekor mencit diberi pakan tinggi lemak dan aquades selama 28 hari

K2 sebanyak 7 ekor mencit diberi pakan tinggi lemak, ekstrak bunga sepatu konsentrasi $25 \%$ sebanyak $1 \mathrm{ml}$ dan aquadest ad libitum selama 28 hari

K3 sebanyak 7 ekor mencit diberi pakan tinggi lemak, ekstrak bunga sepatu konsentrasi 50\% sebanyak $1 \mathrm{ml}$ dan aquadest ad libitum selama 28 hari

K4 sebanyak 7 ekor mencit diberi pakan tinggi lemak, ekstrak bunga sepatu konsentrasi 75\% sebanyak $1 \mathrm{ml}$ dan aquades ad libitum selama 28 hari

\section{ANALISIS DATA}

Analisa data yang digunakan meliputi analisa deskriptif dan analisa inferasial. Analisis inferensial meliputi analisis normalitas dengan uji Kolmogorov-Smirnov dan analisis homogenitas dengan uji Levene Test. Data yang berdistribusi normal dilanjutkan dengan pengujian $\mathrm{T}$ test independent. Setelah mengetahui distribusi dan varian data, maka dilakukan uji $\mathrm{T}$ test independent. Uji analisis yang dilakukan menggunakan software SPSS for window versi 17.

\section{HASIL PENELITIAN}

Hasil penelitian dengan 28 sample menunjukan bahwa pemberian pakan tinggi lemak berhasil menaikkan berat badan tikus secara signifikan. 
Tabel 1. Berat Badan Mencit

\begin{tabular}{|c|c|c|c|c|c|}
\hline Grup & $\begin{array}{c}\text { hari } \\
\text { ke 0 }\end{array}$ & $\begin{array}{c}\text { hari } \\
\text { ke-8 }\end{array}$ & $\begin{array}{c}\text { hari } \\
\text { ke-15 }\end{array}$ & $\begin{array}{c}\text { hari ke- } \\
22\end{array}$ & $\begin{array}{c}\text { hari } \\
\text { ke-30 }\end{array}$ \\
\hline K1 & 16.12 & 19.38 & 22.18 & 23.75 & 25.11 \\
\hline K2 & 15.55 & 19.67 & 22.23 & 22.54 & 21.57 \\
\hline K3 & 15.8 & 19.47 & 22.07 & 20.09 & 18.04 \\
\hline K4 & 15.76 & 19.53 & 21.63 & 17.83 & 16.96 \\
\hline
\end{tabular}

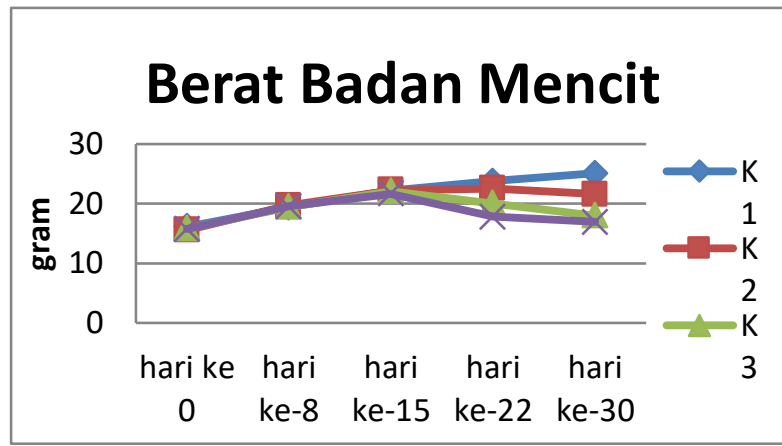

Gambar 1. Peningkatan berat badan mencit

Setelah melalui aklimataisasi selama 7 hari berat badan mencit ditimbang masuk kedalam hasil penimbangan hari ke 0. Selama masa aklimatisasi mencit diberi pakan formula normal. Setelah melalui masa aklimatisasi seluruh kelompok mencit diberi pakan formula tinggi lemak. Kenaikan berat badan mencit mulai terlihat sejak minggu pertama yaitu pada hari penimbangan ke-8. Peningkatan berat badan mencit dapat di lihat pada Gambar 1. grafik peningkatan berat badan mencit.

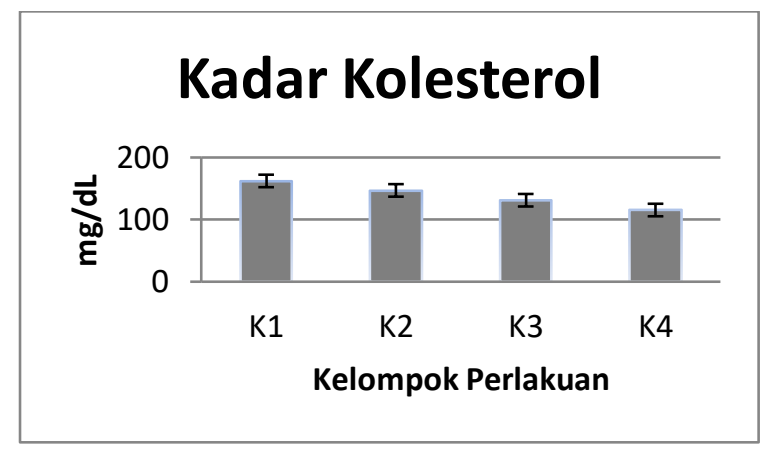

Gambar 2. kadar kolesterol mencit
Berdasarkan hasil penelitian kelompok K1 didapatkan nilai kadar kolesterol paling tinggi dimana kadar total kolesterol sebesar $162.25 \mathrm{mg} / \mathrm{dL}$ dan kelompok K4 didapatkan kadar kolesterol paling rendah sebesar 115.43 $\mathrm{mg} / \mathrm{dL}$.

\section{PEMBAHASAN}

Dari hasil penelitian yang telah dilakukan dengan perlakuan pemberian diet tinggi lemak, kelompok K1 dan K2 mengalami peningkatan berat badan mencit terus menerus sampai dengan hari terakhir perlakuan. Peningkatan berat yang menetap selama periode waktu tertentu dapat menyebabkan obesistas, resiko kenaikan berat badan juga dapat mempengaruhi kadar kolesterol dalam darah.

Hasil penelitian ini sejalan dengan penelitian yang dilakukan oleh Santiago (2010) pada penelitian tersebut didapatkan nilai kadar profil lipid yang diberi pakan tinggi lemak memiliki kecenderungan nilai profil lipid yang lebih tinggi. Asupan diet tinggi lemak jenuh turut meningkatkan kadar kolesterol plasma dengan peningkatan sebanyak 15\%-25\% (Guyton dan Hall, 2006).

Penurunan kadar kolesterol darah dapat menyebabkan penurunan lipid tubuh, dan pada akhirnya dapat menurunkan berat badan, tetapi penurunan tersebut membutuhkan waktu yang lebih lama. Selain itu penurunan berat badan tidak hanya cukup dengan pengurangan asupan makanan tetapi juga dengan peningkatan aktivitas yang dapat 
mengubah kalori menjadi energi (Almatsier, 2003). Hasil penelitian ini menunjukan bahwa pemberian pakan tinggi lemak berhasil menaikkan berat badan tikus secara signifikan.

Pemberian pakan tinggi lemak adalah faktor yang penting dalam peningkatan konsentrasi LDL-C serum. Peningkatan ini menyebabkan kadar LDL-C juga meningkat karena LDL-C merupakan lipoprotein pengangkut kolesterol terbesar pada darah manusia (Gandha, 2009). Hiperkolesterol ditentukan pada hari ke-15 setelah diinduksi diet tinggi lemak, dimana ditandai dengan peningkatan berat badan tikus dan kadar total kolesterol lebih dari $54 \mathrm{mg} / \mathrm{dL}$ dengan nilai normal 10-54mg/dL (Kusumawati, 2004).

Lipid yang berasal dari makanan akan mengalami proses pencernaan di dalam usus menjadi asam lemak bebas, triasilgliserol, fosfolipid dan kolesterol. Di dalam usus asam lemak bebas, triasilgliserol, fosfolipid dan kolesterol diolah dan diserap masuk kedalam aliran darah dalam bentuk kilomikron. Tingginya kadar lipid didalam makanan akan menyebabkan absorsi kolesterol selama proses pencernaan didalam usus mengalami peningkatan. Peningkatan absorsi lipid dapat menyebabkan keadaan hiperkolesterol.

Penurunan kadar kolesterol darah dapat menyebabkan penurunan lipid tubuh, dan pada akhirnya dapat menurunkan berat badan, tetapi penurunan tersebut membutuhkan waktu yang lebih lama.

\section{KESIMPULAN}

Pemberian bunga sepatu dengan konsentrasi selama 28 hari pada pada tikus putih jantan galur wistar dapat menurunkan kadar total kolesterol secara signifikan dimana nilai $\mathrm{p}<0.05$

\section{DAFTAR PUSTAKA}

Almatsier S. 2003. Prinsip dasar ilmu gizi. Jakarta: PT Gramedia Pustaka Utama halaman 64 72, 150, 185-200, 271.

Bonfrate L, Wang DQ, Garruti G, Portincasa P., 2014, Obesity and the risk and prognosis of gallstone disease and pancreatitis. Best practice \& research Clin Gastroenterol; 28: 623-35.

Guyton AC, Hall JE., 2006, Buku Ajar Fisiologi Kedokteran. Edisi 11. Penterjemah: Irawati, Ramadani D, Indriyani F. Jakarta: Penerbit Buku Kedokteran EGC

Hasse JM ML. Krause's food and the nutrition care process. United States: Elsevier Saunders, Medical nutrition theraphy for hepatobiliary and pancreatic disorders; 2012.

Jadhav V.M., Thorat R.M., Kadam V.J. dan Sathe N. S., 2009, Traditional medicinal uses of Hibiscus rosasinensis, Journal of Pharmacy Research, 2(8),1220-1222

Kumar, V., Cotran, R.S., dan Robbins S.L. 2007. Buku Ajar Patologi. Edisi 7; ali Bahasa, Brahm U, Pendt ;editor Bahasa Indonesia, Huriawati Hartanto, Nurwany Darmaniah, Nanda Wulandari.-ed.7-Jakarta: EGC.

Kusumawati D, 2004. Bersahabat dengan Hewan Coba, edisi 1. Yogyakarta: UGM Press, hlm 8-73 
Mayes, PA 2009. Pengangkutan dan penyimpanan lipid dalam Muray, RK, Granner, DK, \& Rodwell, VW, 2009, biokimia Harper, edisi 27, penerbit EGC, Jakarta halaman.225-249

Purwati, S., Rahayuningsih S., Salimar. 2002. Perencanaan Menu untuk Penderita Kegemukan. Jakarta: Penebar Swadaya
Santiago V. A. J., Jayachitra, J., Shenbagam, M. \& Nalini, N., 2010. d-limonene attenuates blood pressure and improves the lipid and antioxidant status in high fat diet and L-NAME treated rats. J. Pharm. Sci. 11, pp.752-758 